ORIGINAL ARTICLE

\title{
Parallel experience: how art and art theory can inform ethics in human research
}

\section{Schwartz}

J Med Ethics; Medical Humanities 2003;29:59-64

Trends in ethical research involving humans emphasise the importance of collaboration, of involving research subjects, alongside the researchers in the construction and implementation of research. This paper will explore parallels derived from another tradition of investigation of the human: art and art theory. An artist's inquiry into the problems of human research will be described, followed by the application of arguments from art theory to research practice. Recently artist Christine Borland has provided examples in which the lack of collaboration in research has caused injustice. Borland's work reflects these ethical dilemmas and questions the procedures and assumptions involved. In most cases the value of subject anonymity is called into question because it reduces the subjects' control over themselves. The application of art theory, which has already considered these problems, helps question and explore the ways in which the subject turned object of artistic or scientific interpretation can maintain some control and dignity.

\footnotetext{
Correspondence to: L Schwartz, Arnold Johnson Chair in Health Care Ethics, McMaster University, Department of Clinical Epidemiology and Biostatistics, HSC 3V43, 1200 Main Street West, Hamilton, Ontario, Canada, L8N 3Z5; schwar@mcmaster.ca
}

Accepted for publication 2 December 2002
$\mathrm{R}$ ecent trends in debate about ethical research involving human subjects have turned toward collaboration, trying to include the researched in the corps of researchers. The trend toward collaboration in human research probably has its roots in greater demands for patient control in the medical context in general: volume 319 of the $B M J$ in 1999 was devoted to this topic. Here the principle of autonomy and patient centred care shape the way health care providers work and ideally generates collaboration and a broader base of responsibility spread between patients and carers. Patients are seeking more control over their treatment, and since medical research involves treatment the same becomes true in research as well. But there may be more to it. Collaborative research may also be welcomed as a form of safeguard. A continuing history of alarming discoveries of so called ordinary research practices involving human subjects reveal research to be a not so new area for concern. The history does not begin with, but is highlighted at the end of the second world war, when the atrocities of the human experimentation by Nazi doctors were revealed. This spurred the creation of the Nuremberg Code and the Declaration of Helsinki which stipulate the parameters of ethical research using human subjects. Now conscientious researchers regularly apply ethical safeguards of informed consent and respect for confidentiality. Nevertheless, ethical problems are ongoing. Currently, disturbing stories about paediatric collection of organs after death are among the most notorious. ${ }^{1}$ Less well known is the routine use in research without consent of Guthrie cards (heel prick test to detect enzyme deficiencies that can lead to severe intellectual disabilities), and antenatal screening samples (to assess the risk of Down's syndrome and spina bifida). Arguably these transgressions could have been avoided if subject communities had been involved in approving or constructing the design of the studies.

The usual justification is that the results of the research could be of benefit to all and it would be a shame to waste such a rich resource. That waiting for informed consent would be too restrictive and would reduce the number of participants. In research that relies on complete samples (such as AIDS studies collected from Guthrie cards ${ }^{2}$ fewer subjects would inhibit successful results. Compliance, if not collaboration, is seen as essential in these cases.

Hornblum demonstrates how in the past American scientists used similar justification to permit certain compromises and abuses even after the results of Nuremberg ${ }^{3}$ :

Domestically, the wellbeing of research subjects was viewed as important, but, in the eyes of medical practitioners, not as important as scientific advancement. Many in the medical community believed the vigorous protection of research subjects, combined with the Hippocratic ideal of primum non nocere ("first of all, do no harm") was too restrictive a code for professional ethics, especially for physicians who had not committed the pseudoscientific outrages of the concentration camps. The result was a marginalisation of the [Nuremberg] code and the creation of an ethical loophole that allowed physicians to pursue a pragmatic and utilitarian course while de-emphasising the code's critical provisions of informed consent by autonomous subjects. Since research was seen to have social importance, doctors could easily avoid the Nuremberg code's prescriptive safeguards and aggressively pursue their individual goals.

The examples demonstrate disregard for engaging in a collaborative effort with research 
subjects, the assumption being that the good of the community can take precedence over the good of the individual, and that sacrifices are acceptable in the name of science.

\section{PROOF IN ART}

In recent exhibitions, artist Christine Borland has provided examples of events in which the lack of collaboration has caused grave injustice and injury, and has not been simply a matter of mere indiscretions. The harm was usually unwittingly directed at research subjects or patients who were taken advantage of, with or without their consent being sought in the first place.

Much of Borland's work reflects these ethical dilemmas and challenges the viewer to question procedures and assumptions involved. In most cases the idea of the value of subject anonymity is called into question as it is demonstrated to reduce individual subjects' control over themselves, parts of themselves or stories about themselves.

Relevant pieces include among others:

- HeLa, Hot 2001, depicting the appropriation of cells from Henrietta Laks, an African American woman who died of cancer in the 1950s. The cells were collected exclusively for diagnostic purposes. But because they reproduce so rapidly, they are now used for research worldwide and can be purchased through laboratory catalogues for a small fee. Consent for their use in research was never sought.

- Genes from The Spirit Collection from Dundee, a photographic essay showing Borland herself retrieving the stored sample of her blood or DNA taken for an antenatal screening test. She never signed a consent form for their storage or use in research, but that is what is being done with her sample and every other screening sample in the UK.
- For Cet etre-la, c'est a toi de le creer! Vous devez la creer! Borland gained access to a closed anatomical museum in Montpelier, France containing specimens collected by French colonialist scientists, air dried and shipped back to France. There can be little doubt they were taken from colonised tribes without consent. The collection is now the subject of controversy over repatriation. Borland was given reluctant permission only to sketch the specimens, but created controversy of her own when she secretly photographed them using a spy camera. Her exhibition clearly raises the question about consent, and asks whose transgression is it anyway?

In each of these works Borland raises questions about the person in the image: who they were, how they intended their participation in the research, and if they would have consented to being part of an artwork.

Initially shocking, perhaps even scandalising, the idea of using actual people or body parts in works of art can be criticised for its own ethical standards. None of the people could have foreseen their involvement or given their consent. But then, as Borland directs our attention, this is true for their research involvement too. Each person appears to have been the subject of injustice, even harm, through being used in the studies without their consent. Henrietta Laks, the nameless and faceless individuals whose body parts were collected for the Montpelier collection, the skeletons employed by students for education-none of these individuals could have known how their flesh, bones, and cells would be used. How many would have consented is unknowable. In many ways the subjects became objects and lost control over their own identities, images, and the very fabric of their being.

Borland's work helps to raise questions about consent in research. The incongruity of the presence of tissue, bone, and blood within an artwork causes contextual strain invoking significant queries about the appropriateness of their use. The exhibitions cause the spectator to ask whether it is suitable

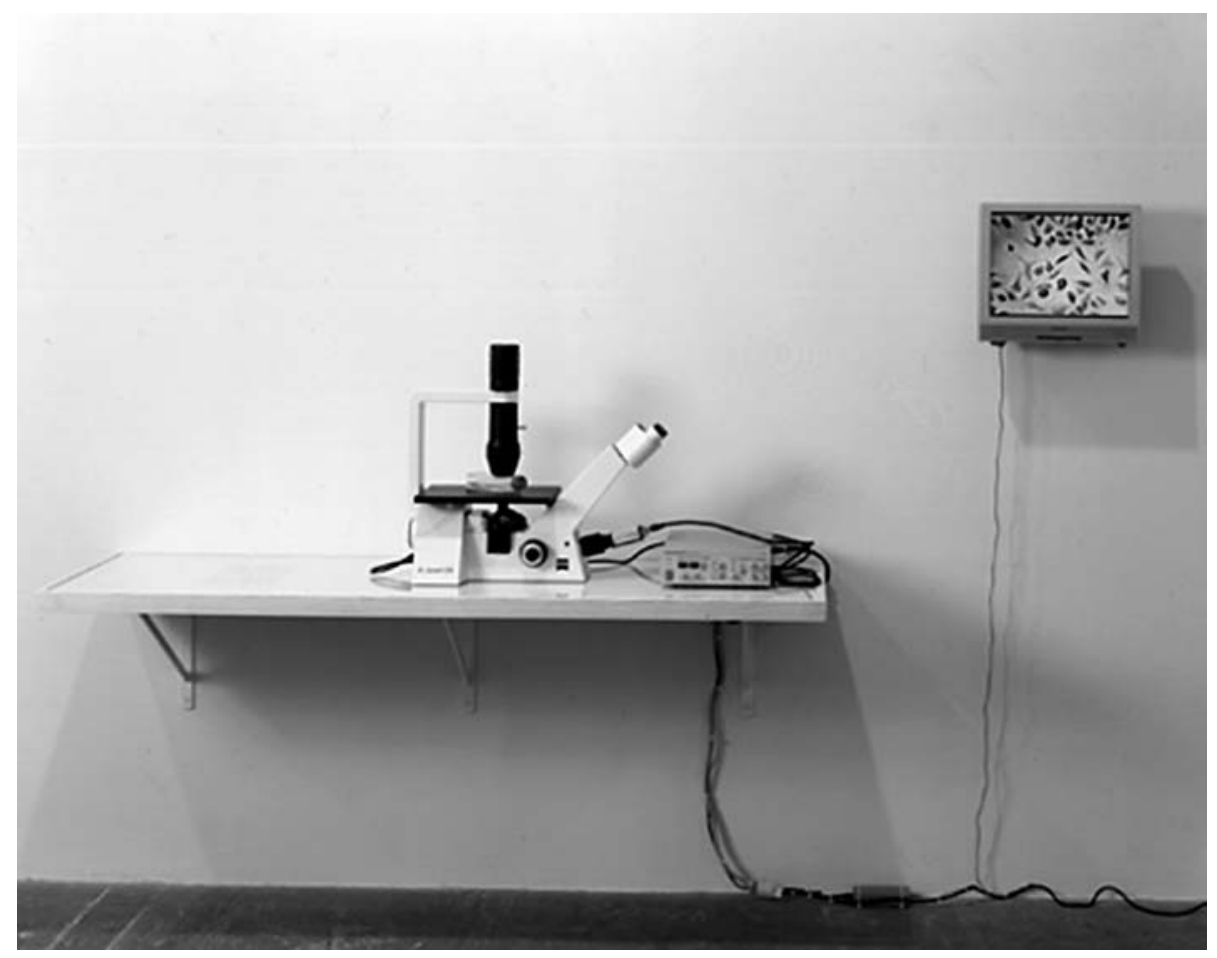

Figure 1: Hela, Hot 2001: Christine Borland. 
for them to be used as part of works of art, triggering the arguably more important question whether it is right for them to be part of research.

\section{CRITICAL RESPONSE}

Art and art theory do not just ask the questions about collaboration, they may help to inform the answers too. The reason for turning to art and aesthetic theory is to consider the notion of the subject of study who becomes an object through the process of being studied. The obvious example of this is the artist's model. Challenges to the idea of control and ownership of outcome have been considered in the artistic context and the debate may shed light on the problems raised so far about loss of control for the research subject.

It is not surprising that feminist artists began to challenge art in the middle decades of the twentieth century. Classically, women's involvement in the arts, at least professionally, was virtually exclusively limited to being models for male artists. They became subjects turned objects of art, whose images were "purloined" as Kelly puts it and manipulated for the purposes of creating universal ideals of beauty and titillation. ${ }^{4}$ Often a faceless interpretation of the subject where images are "disembodied from the personality of their owners". ${ }^{5}$ This has produced an extension of "feminist theory of the 'subject' to a critique of artistic authorship" (Kelly M, ${ }^{4}$ p 249).

The female image in all its variations is the mythical consequence of women's exclusion from the making of art. It is arguable that, despite her ubiquitous presence, woman as such is largely absent from art. We are dealing with the sign "woman", emptied of its original content and refilled with masculine anxieties and desires. ${ }^{6}$

The artists are notoriously criticised for treating models as "chattels_objects of possession, and therefore exchangeable and disposable commodities...". ${ }^{4}$ See also, Dworkin. ${ }^{7}$ Examples include Da Vinci ${ }^{8}$ who sought to reproduce truth in his images; Gainsborough's Mr and Mrs Andrews ${ }^{9}$ which depicts a man with all his possessions; Titian's Venus of Urbino, ${ }^{10}$ and Edward Weston's Shells and Nude. ${ }^{11}$ The models are voiceless. Their images are shaped and employed, then watched and interpreted, far beyond their control. Tickner describes the tradition of Western erotic art and the nude as one where, "man [is] the maker and spectator, woman the passive object of desire" (Tickner L, ${ }^{6}$ p 273). Fisher postulates that the incursions entailed are violent appropriation and possession.

Representation is double appropriation: firstly, the possession of the object by the image maker himself; and secondly by the spectator, who through theft and possession of the image perpetrates a further act of violence" (Fisher J, ${ }^{5}$ p 322).

The language of the feminist arguments is strong and pointed, chosen to demonstrate indignation towards the appropriation of "woman". The critique attempts to revive the subject and reorient the idea of the model as one of participant in a discursive practice. The feminist artists' response was to attempt to regain control and show the self as model in control of her own image, being more "in your face" about the use of the body, and challenging classical ideals of beauty.

Artists such as Cindy Sherman in her Untitled Film Still \#15 and Untitled Film Still \#35, ${ }^{12}$ Hannah Wilke, shown here in examples of photo essays before and during her fatal battle with cancer, and Borland, go beyond traditional conventions of models as objects and use themselves in performance, sculpture, and photo essays that play with expectations of image, of beauty, and of the feminine. Orlan goes so far as to have herself reconstructed, first to match these ideals of perfection and now to push the boundaries of expectation into the grotesque-adding horns and eventually having her nose extended through plastic surgery. ${ }^{13}$

Their critique involves:

... a rejection or parody of the standards by which women are judged sexually desirable, a repossession for our own use of the "colonised" and alienated female body... (Tickner L, ${ }^{6}$ p 275).

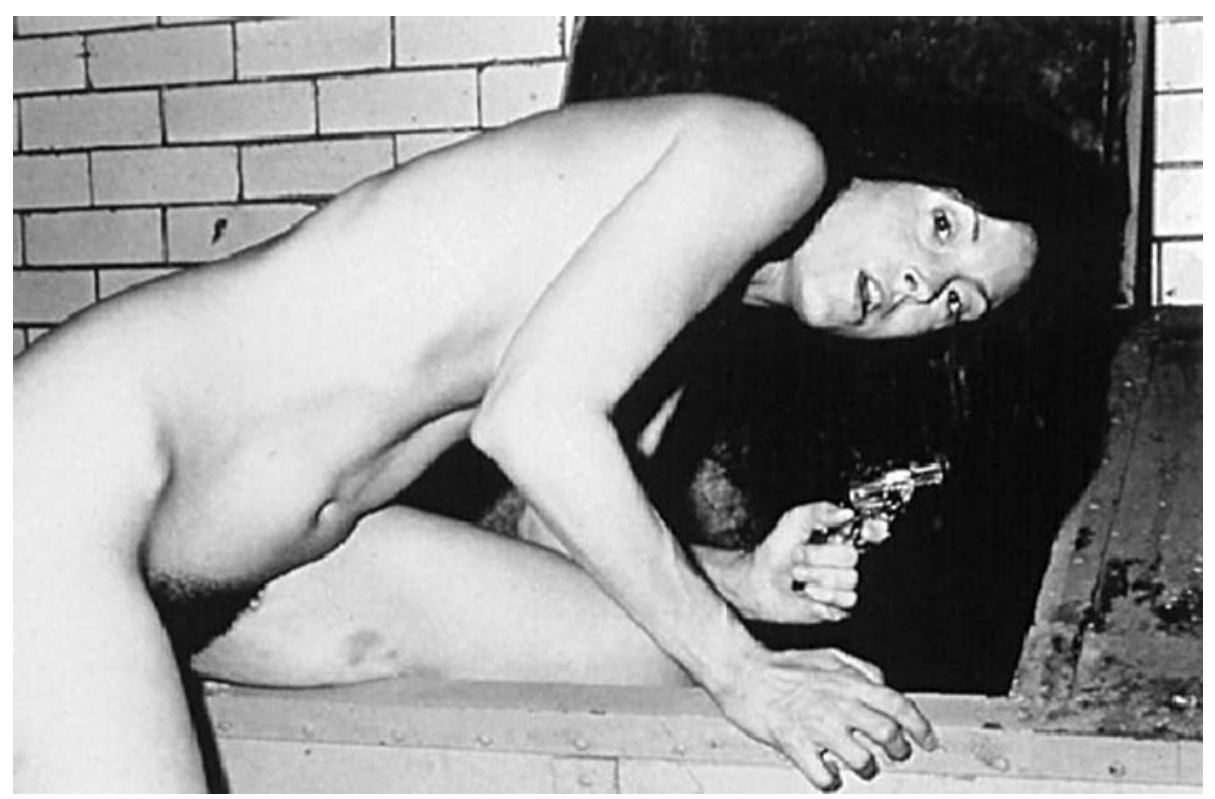

Figure 2: So Help Me Hannah (Snatch Shot with Ray Guns): Hannah Wilke. 


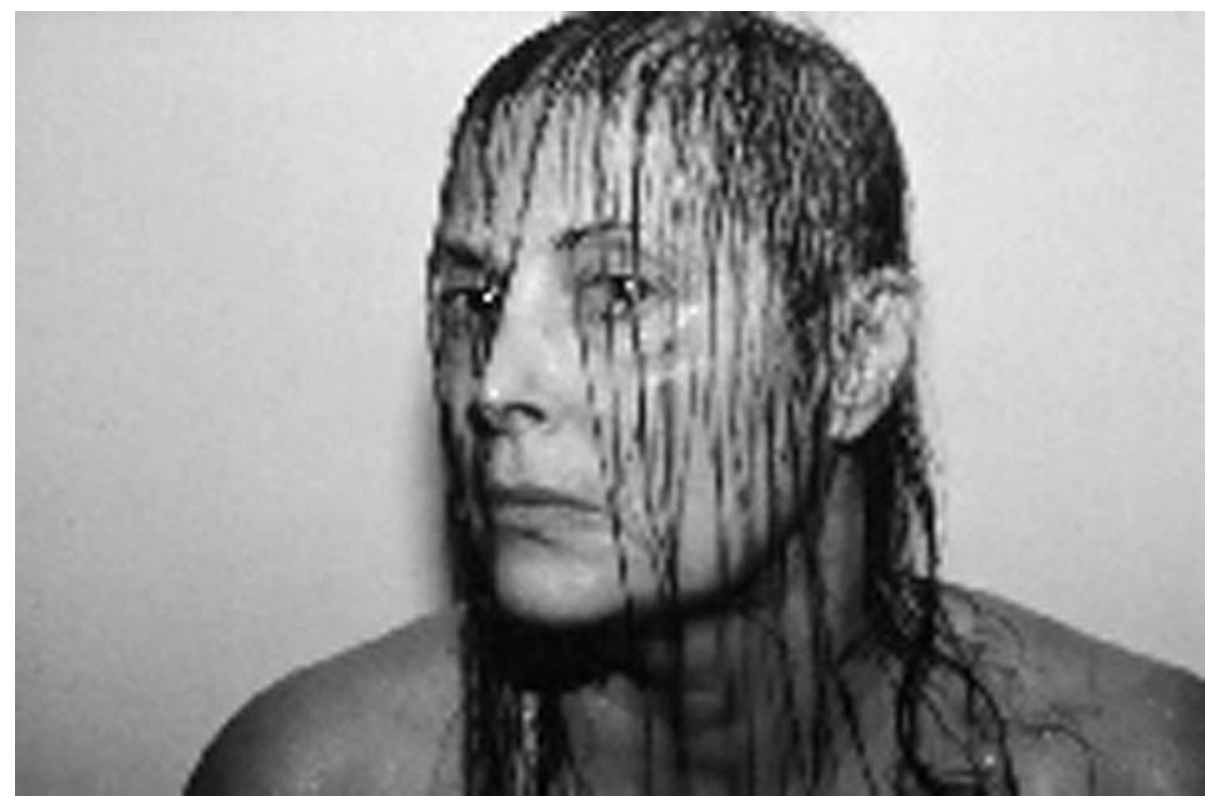

Figure 3: February 19, 1992: \#6: Hannah Wilke.

\section{PARALLELS}

There is scope for applying the same criticisms of the artist to the practice of research even though gender biases happen somewhat differently here. One still finds very few women in control of the situation, but there are comparable numbers of men among the exploited. ${ }^{14}$ In fact, research has been criticised for not including enough women subjects and then trying to extrapolate findings to both sexes regardless of obvious biological differences. Women are more often victims of silencing and ignoring in science. Whereas this may be true of men in certain age groups such as children and the elderly, men are more often the obvious victims of abuse such as the Pennsylvania prison experiments. ${ }^{3}$
The parallels are still pronounced. Even so the parallels with research remain pronounced: in research one finds the obvious appropriation of the image-and even the living or dead tissue-of the person turned object, disempowered and converted into object; reshaped, reinterpreted, reinventedand all beyond the subject's control.

A certain degree of control by the subject (turned object) is believed to exist in scientific research. The law-for example, views research samples as gifts, but the language is conflicting. We often speak of "taking samples" not receiving them. Unlike gifts of other sorts, research gifts can sometimes be taken without the consent or knowledge of the giver. Moreover, tissue samples are retrieved for the purposes of

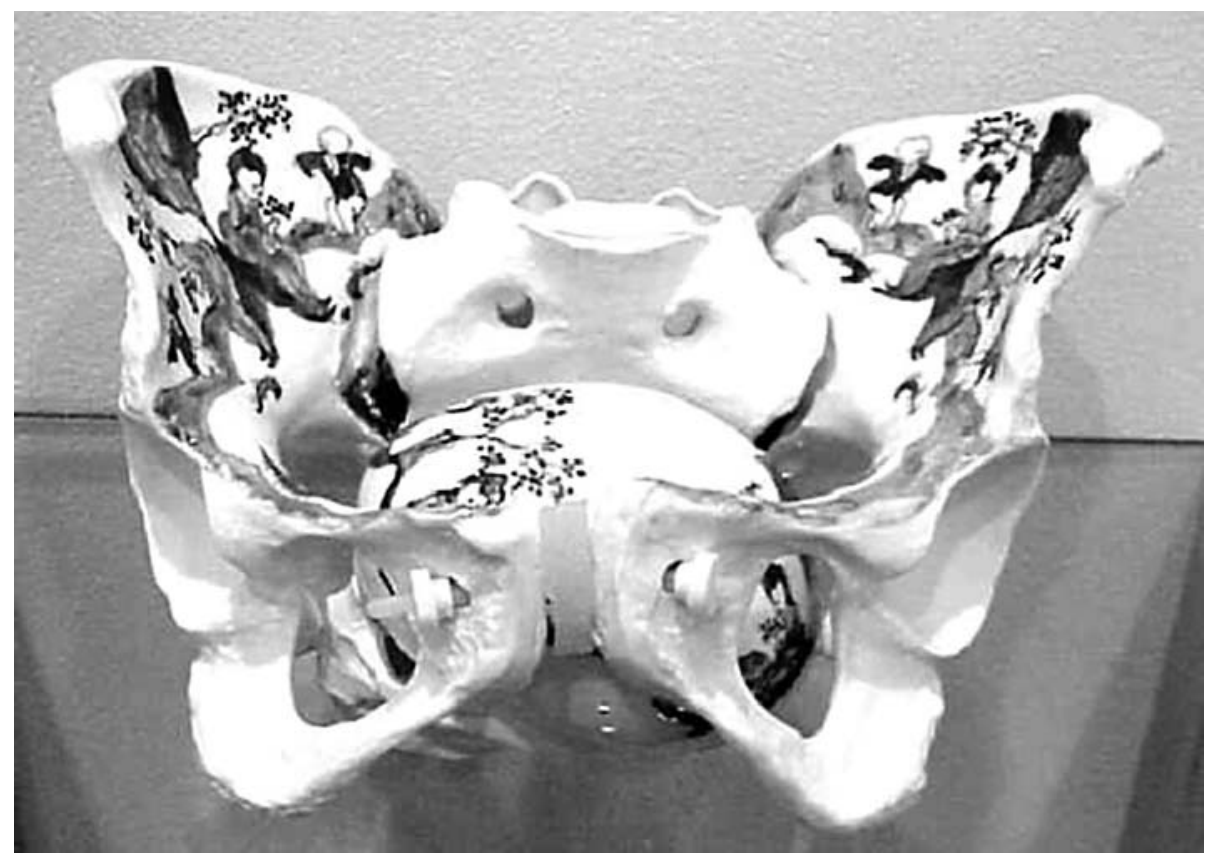

Figure 4: Set Conversation Pieces-Jumping Boy: Christine Borland. 


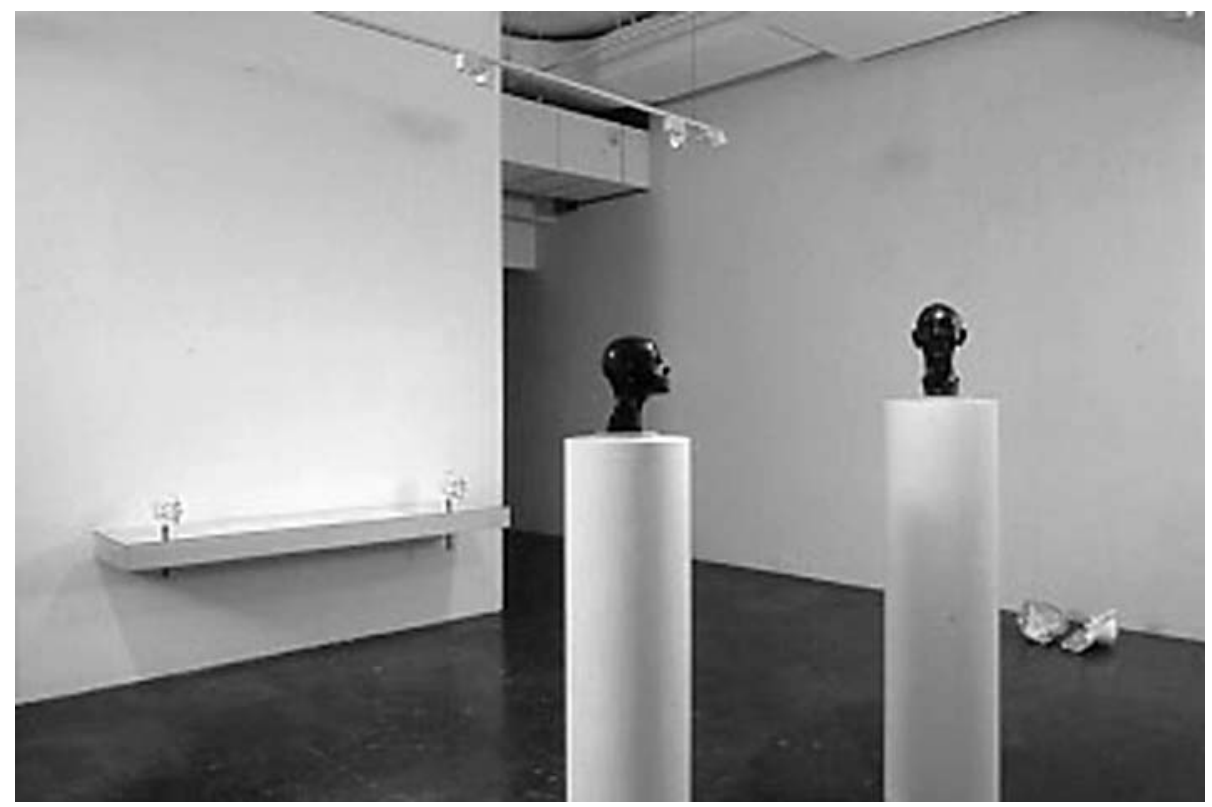

Figure 5: From Life: Christine Borland.

exploitation, the researcher imposing his own interpretation of its value and use. As with other kinds of gifts we cannot specify how they are used, though unlike other gifts we can retrieve them if we think they are being used inappropriately.

Still, examples of loss of control in the research context abound. Hornblum cites many examples in his book Acres of Skin, about the recruitment of inmates in US prisons as human guinea pigs. ${ }^{3}$ Other examples of violations occur in qualitative research where individuals' stories, arguably as precious as tissue if not more so, are transformed and decontextualised for the purposes of research and to inform general statements. Qualitative research does tend, however, to be more self reflective, as papers such as Christine Borland's "'That's not what I said': interpretative conflict in oral narrative research" indicate. Borland reflected upon an excellent example of this when she grappled with the story of her grandmother. ${ }^{15}$ She describes how researchers interested in individuals' stories:

... identify chunks of artful talk ... give them physical existence (most often through writing), and embed them in a new context of expressive or at least communicative activity (usually the scholarly article aimed toward an audience of professional peers). Thus, we construct a second level narrative based upon, but at the same time reshaping, the first. ${ }^{15}$

In research as in art it is the anonymity of the subject that erases the control the subject has over her own image. The moment a subject becomes the object of interpretation she loses control. Her identity is veiled either behind interpretation or research protocols which eliminate what is specifically hers in favour of attempted universalisation and generalisation. Examples of the parallels in art include Da Vinci's search for universal truth about the human body. The question then arises whether and how the individual can or ought to be able to shape the research. Christine Borland's work asks these questions outright.

\section{CONTROL}

There is perhaps one sense in which research subjects, like artist models, maintain a level of influence. The event of objectification involves a degree of interpretation, but the interpretation is not unbound or merely fanciful. It is in some sense directed by and certainly influenced by the subject before the interpreter. As art theorist John Berger put it in regard to the nude:

The way the painter has painted her includes her will and her intentions in the very structure of the image, in the very expression of her body and her face. ${ }^{16}$

The model is therefore inescapable and can impose limitations upon interpretation. Likewise in research but perhaps to a greater degree, the researcher must yield to the subject before him. Attempts at shaping what is offered in the gift of the tissue or the cell etc, must always begin with restrictions imposed by the subject under scrutiny, making it possible to get it wrong. He must acknowledge what is offered or risk accusations of fudging evidence.

But the control can be exaggerated, and the scientists still possess the greater share of it. What is most frightening about interpretational objectification for both the model and the participant in research is first that the process is not value free and second that distortion of the image occurs within a context or indeed a culture to which we are not permitted access (Tickner L, ${ }^{6}$ p 273) as the 1973 US Hearings on Human Experimentation point out.

Those who have borne the brunt of research-whether it is drugs or even experimental surgery-have been the more disadvantaged people within our society; the institutionalised, the poor, and minority members. ${ }^{17}$

In other words the very people who are notoriously excluded from the labs and the academies. This gives too much primacy to the subjective view of the researcher and excludes the view of those being researched, as Hornblum says, quoting senator Teddy Kennedy (Hornblum AM, ${ }^{3}$ p 841). 
The only cure for this is to recognise the political and cultural contexts inherent in the processes that limit so called scientific objectivity. Kelly suggests that in art:

It requires formulating the problem of representation as the product of a practice of signification which will generate questions like "How do the means of signification in a given art practice function?" and only then "What is signified and with what political consequences"? (Kelly $M,{ }^{4}$ p 312).

\section{COLLABORATION}

The solution proposed by artists and art theory is to begin a self analysis, turning the object back into subject as Borland did in From Life. The original exhibition was held at the Tramway, Glasgow. The piece developed from Borland's acquisition of a skeleton originally obtained for educational purposes, but was donated to Borland after it was determined to have imperfections. Borland worked with a forensic sculptor to "recreate" the face based on the skull. The process revealed how much interpretative freedom is required to recreate a face. The work is decidedly controversial, but it did reinvest the object of general learning with a unique value in the context of a work of art, rebuilding the particular identity of the subject and reinvesting it with unique individual value. In Kantian language, it is reasserting the subject as an end in herself, and not solely as a means to artistic or research ends, by intentionally reasserting to a degree her unique facial identity. Collaboration is the most likely way of achieving this goal, in this instance working within established constraints like bone and skull to create something new.

It is relatively easy to see how collaboration can be successful in patient care, but the aims of research are different from those of medicine. Primarily, medicine aims at healing or tending to the illness of a particular person or even group of persons; it is more about the patient than the carer. Research, on the other hand, is less interested in particular individuals (unless they are the researchers ${ }^{2}$ ); more interested in the research than the researched.

Nevertheless, a scan of recent journal literature raises practical possibilities for collaboration in research, especially in the context of genetic prospecting among unique populations. These include: "patients should help to decide which research is conducted, help to plan the research and interpret the data, and hear the results before anybody else $\mathrm{e}^{\prime \prime}{ }^{18}$ They can make "suggestions for new research questions". ${ }^{19}$ The hope is that:

\section{...consumer involvement will greatly enhance the overall relevance of clinical research. It will ensure that the most fruitful research questions are addressed and the most appropriate outcome measures used, thus maximising the potential for the results to be relevant and beneficial to research consumers. Furthermore, it should lead to a more efficient use of research resources." 20}

The claim is that collaboration in research will enhance it and obviate certain failings currently involved. Further benefits include: “... that patients (participants, users, consumers, what you will) have the experience and skills that complement those of researchers. They know what it feels like to suffer a particular disease and to undergo the treatments with their various side effects. They will have a good idea of which research questions are worth asking, and when a question should be framed differently." And the requirements involved "are likely to ensure greater rigour and relevance for future research". ${ }^{19}$ Finally, participation promotes interest and cooperation which researchers are dependent on to test their hypotheses. ${ }^{21}$

For our purposes, collaboration in research restores subjectivity to the object of research by passing back some control over image and interpretation, just as artists' models regained control of their images by becoming artists themselves or drawing our attention to their involvement form the start.

As Pappworth put it (later recalled by Hornblum):

No physician is justified in placing science or the public welfare first and his obligation to the individual, who is his patient or subject, second. No doctor, however great his capacity or original his ideas, has the right to choose martyrs for science or for the general good.."22

Artists and art theorists help raise the questions and explore the ways in which the object of artistic or scientific interpretation can maintain some control and dignity.

\section{ACKNOWLEDGEMENTS}

Thanks to Sue Brind, without whom this paper would not have been possible. Scans of work by Christine Borland appear with permission of the artist. Scans of work by Hannah Wilke appear with permission of the Feldman Gallery, copyright 2003 Donald Goddard, courtesy Ronald Felman Fine Arts, New York.

\section{REFERENCES}

1 Bauchner $\mathbf{H}$, Vinci R. What have we learnt from the Alder Hey affair? BMJ 2001;322:309-10.

2 Braunack-Mayer A, Rogers W. Handling information ethically: some strategies for discussion. Aust Fam Physician 2000;29:1005-8.

3 Hornblum AM. Acres of skin: human experimentation at Holmsburg Prison-a true story of abuse and exploitation in the name of medical science. New York: Routledge, 1998:xvii.

4 Kelly M. Beyond the purloined image. In: Parker R, Pollock G, eds. Framing feminism: art and the women's movement 1970-1985. London: Pandora Press, 1987:249-53.

5 Fisher J. Object of fetishism. In: Parker R, Pollock G, eds. Framing feminism: art and the women's movement 1970-1985. London: Pandora Press, 1987:322-3.

6 Tickner L. The body politic: female sexuality and women artists since 1970. In: Parker R, Pollock G, eds. Framing feminism: art and the women's movement 1970-1985. London: Pandora Press, 1987:263-76.

7 Dworkin A. Pornography: men possessing women. New York: Putnam, 1981.

8 Artchive. http://artchive.com (accessed 5 Aug 2003).

9 Artchive. http://artchive.com (accessed 5 Aug 2003).

10 Artchive. http://artchive.com (accessed 5 Aug 2003).

11 Masters of Photography. http://masters-of-photography.com laccessed 13 Aug 2003).

12 Masters of Photography. http://masters-of-photography.com (accessed 5 Aug 2003).

13 Orlan Gallery. www.orlan.gallery.htm (accessed 5 Aug 2003).

14 Rosser SV. Women's health-missing from US medicine. Bloomington: Indiana University Press, 1994.

15 Borland C. "That's not what I said": interpretative conflict in oral narrative research. In: Perks R, Thomson A, eds. The oral history reader. New York: Routledge, 1998:320-32.

16 Berger J. Ways of seeing. London: BBC and Penguin Books, 1972:58.

17 Gadamer HG. The nature of things and the language of things. Philosophical hermeneutics. Berkeley: University of California Press, 1976:69-81.

18 Goodare H, Smith R. The rights of patients in research. BMJ 1995;310:1277-8

19 Goodare H, Lockwood S. Involving patients in clinical research improves the quality of research. BMJ 1999:319:724-5.

20 Tallon D, Chard J, Dieppe P. Consumer involvement in research is essential. BMJ 2000;320:380.

21 Macaulay A, Commanda LE, Freeman WL, et al. Participatory research maximises community and lay involvement. BMJ 1999:319:774-8.

22 Pappworth MH. Human guinea pigs. Boston: Beacon Press, 1967:27. 